\title{
Effects of human disturbance on broods of Red-breasted Mergansers Mergus serrator
}

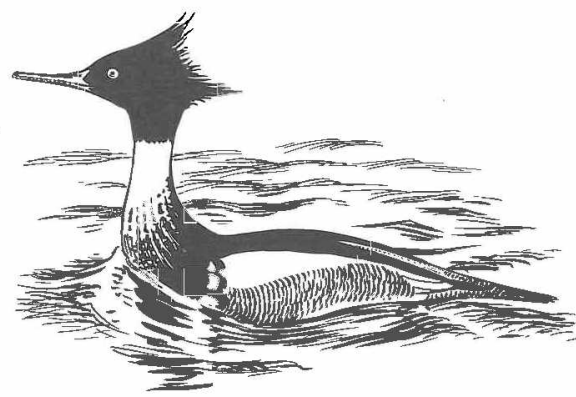

\section{JOHNNY KAHLERT}

The effects of human disturbance on broods of Red-breasted Mergansers were studied at three Danish localities. Fast-moving boats (fishermen, windsurfers, and motor boats) were considered to have the greatest impact on Merganser broods as frequency of encounters and rate of disturbance were highest. The presence of fast-moving boats also caused the most significant modifications to time budgets. However, Merganser broods are considered quite resilient to human disturbance as they quickly resumed their former activities after disturbance, and at moderate disturbance levels, interruptions to comfort behaviour were compensated for within $1^{1 / 2}$ hours. However, on one locality with high disturbance levels and frequent high-speed boating, the survival of ducklings was reduced.

Keywords: Denmark, Rivers, Breeding, Rearing, Disturbance, Boats, Red-breasted Merganser

During the last 20 years, most studies of recreational activity in Northern Europe have revealed major increases in the leisure use of coastal areas (e.g. Prater 1981, Laursen 1982, Matthews 1982, Brouwer \& Daalder 1984, Dietrich \& Koepff 1986). With the prospects of increased tourism (Edington \& Edington 1986, Vandermotten 1990), there is no reason to assume that recreational pressure will be reduced in coming years. For future management of coastal areas it is therefore important to know how waterfowl respond to human activity.

Around the Baltic coasts, the Red-breasted Merganser Mergus serrator is a common breeder. Ducklings are reared from June to October (Cramp \& Simmons 1977), so that the brood-rearing period coincides with the tourist season when recreational activities are most frequent. However, little is known about how species that rear their young during the summer cope with human activities. Ảhlund \& Götmark (1989) suggested that Red-breasted Mergansers and other late-breeding species may suffer from reduced reproductive success due to intense disturbance.

In the present study, the consequences of disturbance on Merganser broods were examined with respect to the following questions: 1) how frequently are Merganser broods disturbed by the presence of human activity; 2) do the birds discriminate between different kinds of human activity; 3) for how long after disturbance are the activities of the broods influenced; 4 ) are they able to compensate for the time lost by disturbance, by allocating more time afterwards to the activities which were interrupted (Schilperoord \& Schilperoord-Huisman 1981, Madsen 1985, Madsen et al. 1992) and 5) is duckling survival influenced by frequency and composition of disturbance events. The answers to these questions are synthesized into an evaluation of the resilience of Merganser broods to human disturbance.

\section{Methods}

The study was carried out in three areas (Table 1) in Lillebælt, Denmark $\left(55^{\circ} 20^{\prime} \mathrm{N}\right.$, $9^{\circ} 45^{\prime} \mathrm{E}$ ). Each area was visited every 1 to 5 days from 22 July to 14 August 1991 and from 3 July to 11 September 1992.

Human activities and activities of Merganser ducklings were recorded by instantaneous scanning (Altmann 1974). The scans (=observations) were carried out every 5 minutes, and the daily observation period lasted 1-9 hours. For each human activity it was noticed whether the nearest brood was disturbed. A disturbance was defined as a stimulus source (human activity) to which the birds clearly reacted by moving away. In the present paper 'disturbance' is distinguished from 'human activity' by the fact that the latter simply refers to the presence of people, engaged in activities not disrupting to the birds. The observation points were sufficiently remote $(300-500 \mathrm{~m})$ that the activity of the broods 
Table 1. Description of study areas

\begin{tabular}{lllllc}
\hline Area & $\begin{array}{l}\text { Size } \\
\left(\mathrm{km}^{2}\right)\end{array}$ & Habitat & Year & $\begin{array}{l}\text { Broods } \\
\text { observed }\end{array}$ & $\begin{array}{c}\text { Observation } \\
\text { time (hours) }\end{array}$ \\
\hline Hejls & 2.8 & Estuary & 1991 & 8 & 51 \\
Hejls & 2.8 & Estuary & 1992 & 20 & 87 \\
Guds $\varnothing$ & 3.6 & Estuary & 1992 & 8 & 105 \\
Årø & 2.0 & Inlet & 1992 & 7 & 108 \\
\hline
\end{tabular}

was not influenced by the observer.

The activities of the broods were divided into five categories - forage, comfort, swim, sit on water and other activities. Furthermore, it was noted whether the birds were on land or in the water. Comfort included rest and preen; the category 'sit on water' was composed of more behaviours, however, my impression is that this activity category was due mainly to disruption when disturbed. The ducklings were considered as a group so that the activity performed by most ducklings determined the activity of the group (Bregnballe \& Madsen 1990).

Human activity included eight categories - fishermen, windsurfers, motor boats, other boats, walkers, other activity on foot, dogs, vehicles and aircraft. Fishermen were primarily using motor boats, and were either eelers or trap fishers. 'Other boats' included sailing boats, rowing boats, canoes, and rafts. Bathers, anglers, and worm diggers were placed into 'other activity on foot'. 'Vehicles and aircraft' were either bicycles, agricultural machinery, or helicopters and jet-fighters from a nearby military airfield.

Time budgets were calculated for each type of human activity; all 5 minute periods with more than one kind of human activity were excluded from the analysis. In an analysis of duckling activity before a disturbance, data were excluded when the broods had been disturbed during the two hours prior to the incident being studied.
Data were pooled from one hour before a disturbance; however, the last 15 minutes before a disturbance were excluded, as observations in this period, for some unknown reason, differed from the other observations before a disturbance. After disturbance, data were pooled into 15-minutes periods to ensure a reasonable sample size.

Broods could be recognized during the study period due to brood size, habitat use, and age of ducklings. Duckling age was estimated by body size and plumage with a accuracy of three days. Assuming no immigration or emigration of broods, the breeding success was calculated based on counts of newly-hatched broods (0-3 days old) and broods reaching independence (45 days old). The breeding success was tested by $\chi^{2}$-statistics at the individual level. This is justified by the fact that a brood is not a 'constant' unit in Red-breasted Merganser. Individual ducklings actually float between different broods as a result of accident, and females giving up their broods (Bergman 1956, Kahlert in prep.).

\section{Results}

\section{Responses to human activities}

When disturbed, the typical reaction of the ducklings was to clump around the caring

Table 2. Frequency and rate of disturbance to Merganser broods

\begin{tabular}{lccc}
\hline Activity & \multicolumn{2}{c}{ events $n$} & Rate of disturbance (b/a) \\
\cline { 2 - 3 } & Human activity (a) & Disturbance (b) & \\
\hline Boats & 322 & 56 & 0.17 \\
$\quad$ Fishermen & 79 & 13 & 0.16 \\
Windsurfers & 109 & 15 & 0.14 \\
Motorboats & 43 & 3 & 0.07 \\
Other boats & 227 & 17 & 0.07 \\
On foot & 173 & 4 & 0.02 \\
$\quad$ Walkers & & & 0.00 \\
Other activity & 29 & 0 & 0.23 \\
Others & 44 & 10 & \\
$\quad$ Dogs & & & \\
Vehicles, aircraft & & &
\end{tabular}


Table 3. Percentage of time spent in water by Merganser broods when they encountered different kinds of human activities

\begin{tabular}{llc}
\hline Activity & $\begin{array}{l}\text { Time spent } \\
\text { in water }\end{array}$ & $\begin{array}{l}\text { Obs. } \\
n\end{array}$ \\
\hline Boats & & 329 \\
Fishermen & $69.0^{* *}$ & 112 \\
Windsurfers & $84.8^{* \star *}$ & 108 \\
Other boats & $72.2^{*}$ & 243 \\
On foot & & 163 \\
Walkers & $63.8 \mathrm{NS}$ & 3978 \\
Other activity & $66.3 \mathrm{NS}$ & 6.9 \\
No activity & 60.9 & \\
\hline
\end{tabular}

ancludes all boats which are not fishermen or windsurfers.

$\mathrm{b}_{\neq^{2}}$-test for different activities $v$ no activity, ${ }^{*}: P<0.05$,

${ }^{* *}: P<0.01,{ }^{* * *}: P<0.001$, NS: non-significant $(P>0.05)$.

female and then swim rapidly away from the source of disturbance. Only on one occasion were ducklings and female seen diving; and in one case the female flew away as a response to disturbance. These two incidents were both caused by fishermen in motor boats heading directly towards the broods. On a further two occasions, fisher- men caused the temporary break-up of broods, these lasted 22 minutes and at least 9 minutes. These examples of dramatic responses towards one specific activity indicate that the broods discriminate between different human activities. This differentiation between activities was further demonstrated in the rate of distur-

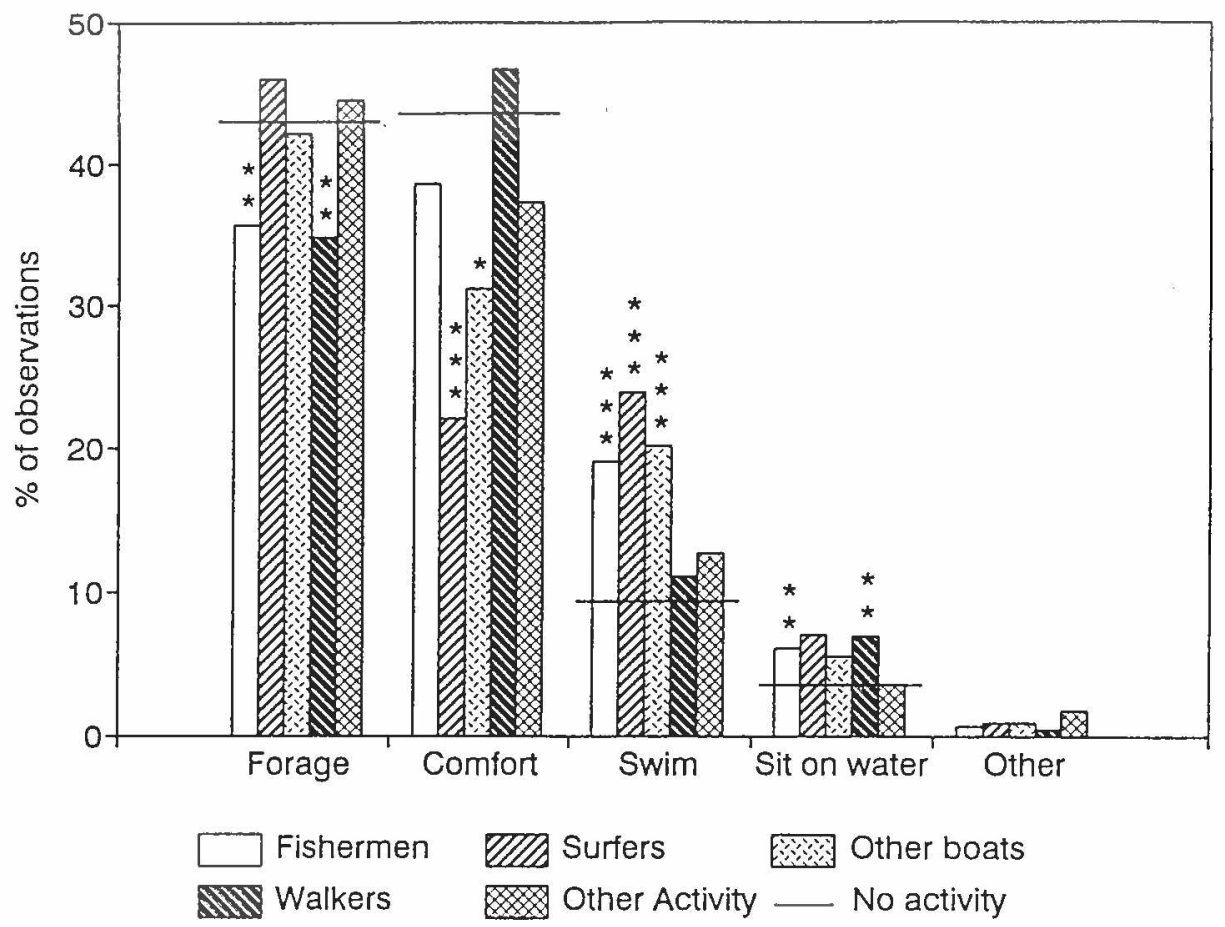

Figure 1. Time budgets of Merganser broods when different types of human activity were present in the observation area. $\chi^{2}$-statistics; no activity $v$ presence of different activities, ${ }^{*}: P<0.05$, ${ }^{*}: P<0.01$, $* * *: P<0.001$. 
bance (Table 2), as the broods responded twice as often to the fast moving boats (including fishermen, windsurfers, and motorboats) compared to walkers $\left(\chi^{2}=10.78\right.$, $\mathrm{P}<0.001)$. The highest rate of disturbance was found in the category 'vehicles and aircraft' $(0.23)$, mostly from helicopters and jet-fighters, which caused disturbance in all seven of their encounters with Merganser broods.

There was no relationship between the rate of disturbance and the number of events where human activities were present, e.g. the fast-moving boats (fishermen, windsurfers, and motor boats) all gave a high rate of disturbance, although the frequency of these activities was quite different (Table 2).

\section{Effects on time budgets of human activities}

Water-based activities had the greatest impact on the time budgets of the broods; for example, in the presence of human activities, the time spent in the water increased between 3 and $24 \%$ over periods with no human activity (Table 3). Windsurfers had the most significant effect. Also in the detailed analysis of brood activity, major changes were observed (Figure 1). In particular, water-based activities made the broods move around: (Swim, all boats v no activity, $\chi^{2}=61.03, P<0.001$; All by foot $\mathrm{v}$ no activity, $\chi^{2}=2.46, P=0.12$ ). The broods also spent more time sitting on water but this was only significant when fishermen or walkers were present (Figure 1). With a few non-significant exceptions, the extra time spent on swimming and sitting on water reduced the time available for foraging and comfort (Figure 1).

\section{Effects after human disturbances}

In most incidents the period of disturbance was short. For example, during the rearing

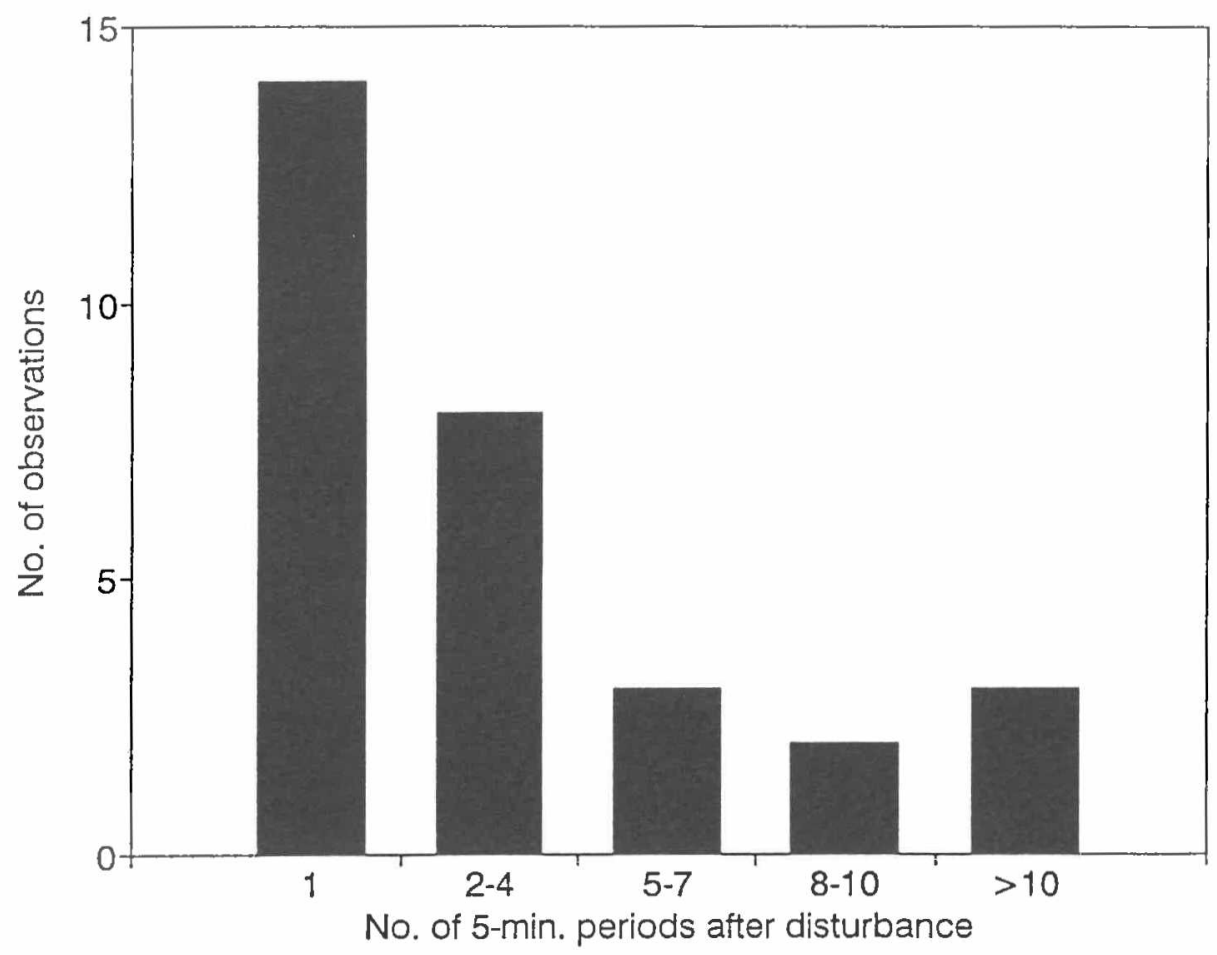

Figure 2. Frequency of the number of 5 minute periods it took before Merganser broods resumed the activity they were involved in immediately before a disturbance. Only 'forage' and 'comfort' are considered. 

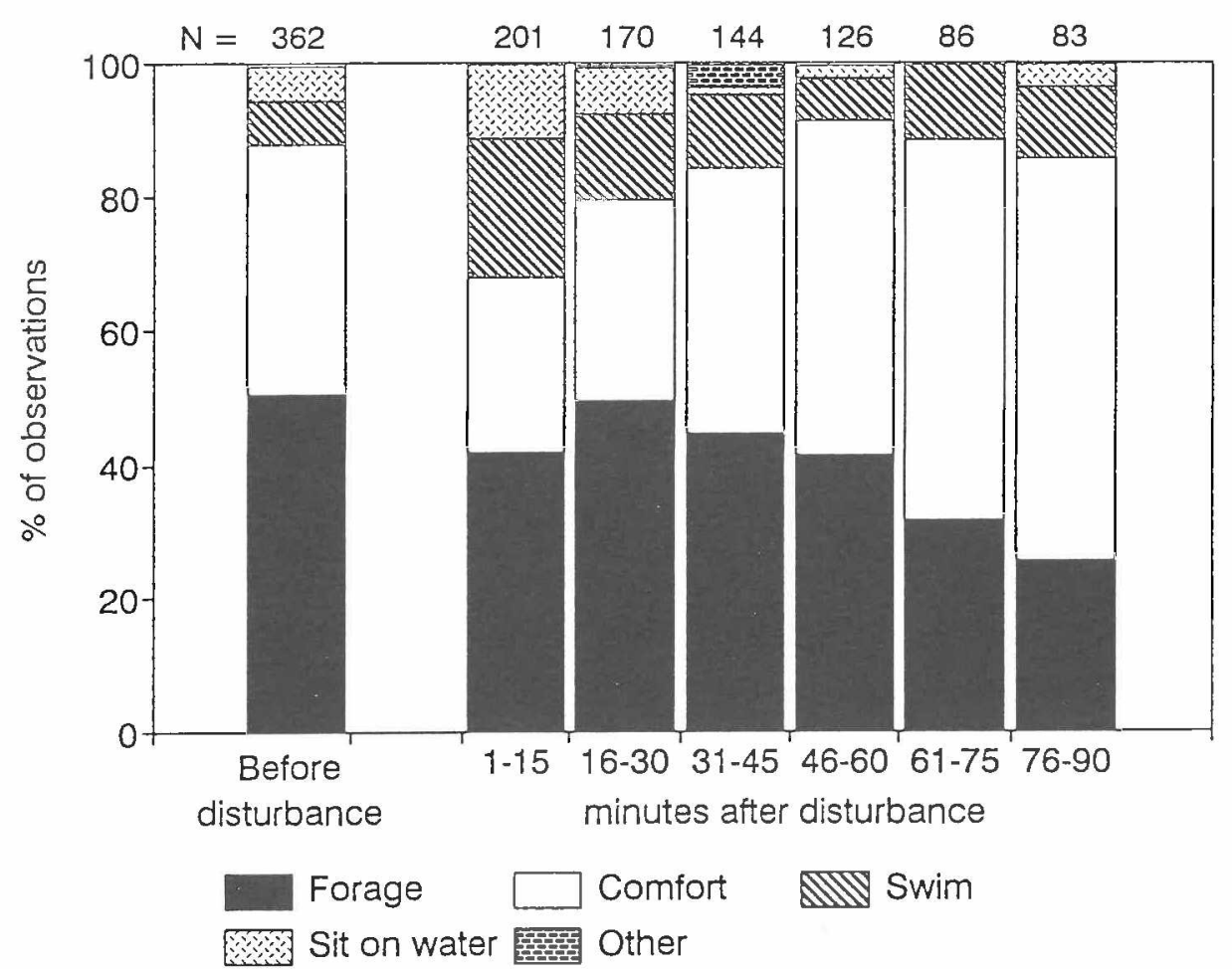

Figure 3 . Time budgets of Merganser broods before and $1^{1 / 2}$ hours after a disturbance. $n=$ number of observations.

period in 1991 eight broods were followed continuously in Hejls. Disturbance to broods was noted 20 times. Eight of these disturbance events were categorized as short $(0-30 \mathrm{sec})$. Longer lasting disturbances $(>30 \mathrm{sec})$ averaged 3.00 minutes (range 0.5-10.7 min). From data gathered in 1992, it was calculated how many 5 minute periods it took before the broods performed the same activity as the 5 minute period immediately before the disturbance. In about half of the incidents the former activity was resumed in the 5 minute period immediately following the disturbance (Figure 2). With short disturbance, the broods in most cases were seen to move less than $100 \mathrm{~m}$ when disturbed.

The short period of disturbance was also reflected in the time budget after a disturbance (Figure 3). Right after a disturbance (1-15 minutes), broods allocated more time to swimming around, but soon the percentage of swimming rapidly decreased (swimming, all time categories after disturbance; $\chi^{2}=16.69, \quad P=0.005 ; \quad \chi^{2}$-contribution from (1-15) was 8.99). The same pattern of time allocation after a disturbance was noticed in the category 'sit on water' (sit on water, all time categories after disturbance; $\chi^{2}=27.93, P<0.001$ ).

Bearing in mind that the presence of human activities can constrain the time available for comfort behaviour and foraging (Figure 1), it should be expected that this effect would be particularly clear after a disturbance. Time spent foraging decreased immediately after a disturbance but not significantly $(P>0.05)$ (Figure 3 ). Comfort behaviour was seemingly most affected by disturbance as the first period after disturbance (1-15) had a significantly lower level in percentage comfort time $\left(\chi^{2}=7.06, P=0.006\right)$. Hereafter, percentage of comfort behaviour increased and reached a plateau in the periods (46-60), (61-75), and (76-90 minutes after disturbance) which was significantly higher than before the disturbance $\left(\chi^{2}=6.26-14.64, \quad P<0.02\right)$. 


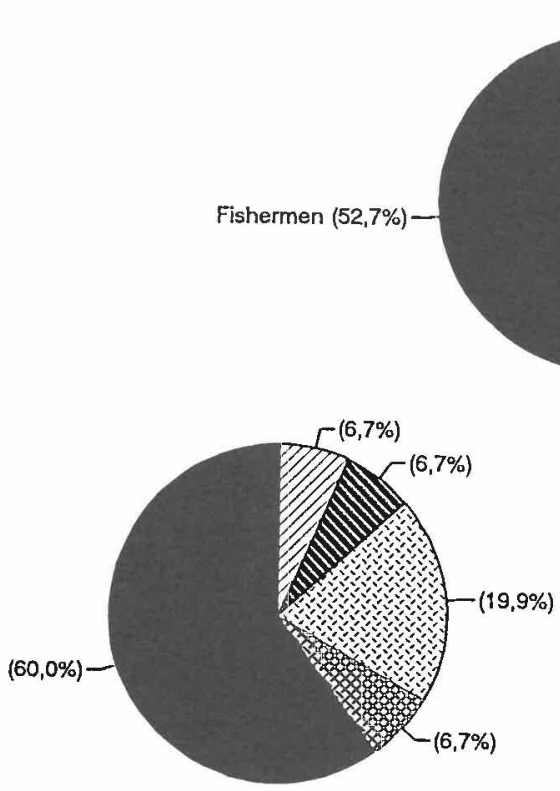

A

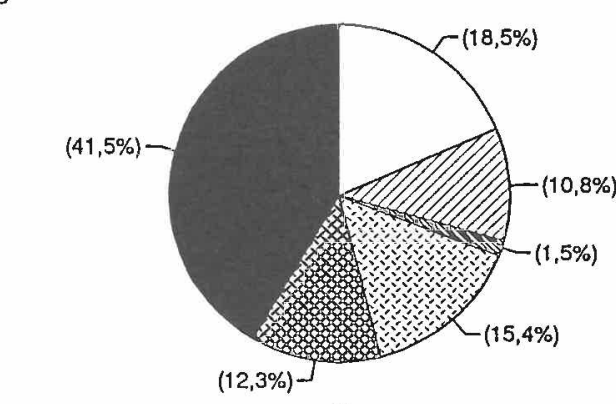

C

Figure 4. Percentage of different sources of disturbance to Mergansers in Hejls (A), Gudsø (B), and Årø (C).

This increased allocation of time to comfort behaviour significantly depressed the foraging time in the periods (61-75) and (76-90 minutes after disturbance, $\chi^{2}=9.95$ $16.98, P<0.003)$. In total the foraging deficit after a disturbance was $9.3 \% \quad\left(\chi^{2}=8.77\right.$, $P=0.003)$. By comparison, the reduction in comfort behaviour immediately following a disturbance (1-15 and 16-30 minutes after disturbance) was fully compensated within $1^{1 / 2}$ hours, i.e. the difference in percentage of comfort actions before and after a disturbance (all periods) was only $2.5 \%$ $\left(\chi^{2}=0.64, P=0.43\right)$.

\section{Long-term effects}

So far the immediate effects of disturbance on Merganser broods have been described in general terms, but what are the effects of living where there are different frequencies and compositions of human activities?

In all study areas, activities by fishermen were most frequent and caused most disturbance (Figure 4, see also Table 2). However, there were some differences in the composition of disturbance in the three study areas. Expressed in percentages there were more disturbing events on foot and fewer by boat in Hejls in comparison with Gudsø and Årø (Figure 4); due to small sample sizes, these tendencies could not be verified by $\chi^{2}$-statistics $(P>0.35)$. Regarding specific activities, the main difference between areas was that windsurfers caused almost one fifth of all disturbance in Årø (Figure 4C), while windsurfers were almost absent in Hejls and Gudsø (Figure 4A-B) (Fisher's exact test, 2-tailed, $P=0.006$ ).

Overall the broods in Gudsø and Årø were disturbed six and seven times as often, respectively, as the Mergansers in Hejls, although only the Årø broods differed in their time budget (Table 4). In that area there was a tendency for less time to be allocated to comfort and more time to water-based activities such as foraging, swimming, and sitting on water. The most remarkable differences were noticed in comfort behaviour and in 'sitting on water'. More than half of the broods and ducklings in Årø did not reach independence compared to about one fourth in Hejls and Gudsø (Table 5). 
Table 4. Frequency of disturbances and time budget of Merganser ducklings in the three study areas

\begin{tabular}{|c|c|c|c|c|c|c|c|}
\hline \multirow[t]{2}{*}{ Area } & \multicolumn{3}{|c|}{$\begin{array}{l}\text { Disturbances }^{\mathrm{a}} \mathrm{n} \\
(\text { Mean } \pm \\
\mathrm{SE}^{\circ} \mathrm{h}^{-1}\end{array}$} & \multicolumn{2}{|c|}{ Time budget $(\%)^{b}$} & \multirow[b]{2}{*}{ Others } & \multirow[b]{2}{*}{$\begin{array}{l}\text { Activity } \\
\text { in water }\end{array}$} \\
\hline & & Forage & Comfort & Swim & $\begin{array}{l}\text { Sit on } \\
\text { water }\end{array}$ & & \\
\hline Hejls & $0.06 \pm 0.03$ & 41.0 & 44.8 & 10.6 & 3.3 & 0.3 & 58.9 \\
\hline Guds $\varnothing$ & $0.37 \pm 0.16$ & 40.9 & 44.4 & 11.3 & 2.9 & 0.5 & 59.3 \\
\hline Årø & $0.44 \pm 0.13$ & 43.3 & 38.6 & 11.3 & 6.2 & 0.6 & 68.8 \\
\hline
\end{tabular}

ane-way ANOVA, F $=3.13, P<0.1 . n=15 ; 38$; and 65 disturbances.

$x^{2}$-statistics within each activity category. Hejls v Gudsø: non-significant in all categories $P>0.05$. Hejls vs. År : significant $(P<0.05)$ in 'comfort' $\left(x^{2}=14.84, P<0.001\right)$, 'sit on water' $\left(x^{2}=16.23, P<0.001\right)$, and 'activity in water' $\left(x^{2}=38.97, P<0.001\right)$. Guds $\varnothing \mathrm{v}$ Arr : significant $(P<0.05)$ in 'comfort' $\left(x^{2}=12.42, P<0.001\right)$, 'sit on water' $\left(x^{2}=20.53, P<0.001\right)$, and 'activity on water' $\left(x^{2}=34.25, P<0.001\right) . \mathrm{n}=1670 ; 1527$; and 2090 observations.

Table 5. Breeding success of Red-breasted Merganser in three study areas

\begin{tabular}{lll}
\hline Area & \multicolumn{2}{l}{$\%$ of newly-hatched reaching independence } \\
\cline { 2 - 3 } & Broods (n) & Ducklings (n) \\
\hline Hejls & $75(20)$ & $74(138)$ \\
Guds $\varnothing$ & $75(8)$ & $71(48)$ \\
Årø & $57(7)$ & $53(66)$ \\
\hline
\end{tabular}

Ducklings Hejls v Årø $x^{2}=9.04, P<0.01$

\section{Discussion}

\section{Consequences of disturbance}

Most studies have shown that waterfowl react strongly to aerial activity (Owen 1973, Owens 1977, Berger 1977, Leito \& Renno 1983, Mosbech \& Glahder 1991). This is confirmed in the present study as the Merganser broods responded every time they saw aircraft. Two factors may be responsible for this. First, low flying aeroplanes are noisy, and secondly, the Merganser broods were not familiar with this kind of activity. However, the fact that the frequency of encounters was low suggests that the negative impact on Merganser activities is small. This suggestion is supported by the fact that aerial disturbance was short (overflying), and that the broods quickly resumed their former activity after interruption.

Instead, what actually seemed to affect Merganser broods was human activity performed by boat and on foot. In that respect, the present study was consistent with most other studies of waterfowl which showed that water-based activities were the most disturbing (e.g. Pedroli 1983, Tuite et al. 1984, Schneider 1987, Åhlund \& Götmark 1989). Undoubtedly the speed at which these activities were performed had some effect; the fast-moving boats (fishermen, windsurfers, and motor boats) caused relatively more disturbance than slow ones ('other boats'). On that basis, it is not surprising that fast-moving boats had the greatest impact on the time budgets of Mergansers by forcing them to move around searching for undisturbed areas. Windsurfing was an especially prominent source of disruption to broods, probably due to high speed and the unpredictability of their movement (Brouwer \& Daalder 1984, Dietrich \& Koepff 1986). In contrast to the fast-moving boats, activity on foot appeared to have a less negative influence on the activities of Merganser broods. Activities on foot did not induce significantly more swimming compared with the water-based activities; at most, the broods showed anxiety expressed by sitting on the water or by preening (comfort) as a displacement activity. Furthermore, the broods did not seek refuge in the water (Burger 1981) after seeing humans on foot.

However, the increase in the amount of time spent on the water, especially when windsurfers were present, need not necessarily be negative insofar as a part of this extra time on the water was apparently used for foraging. Assuming no variance in the food availability between areas, the in- 
terpretation of this result is: first, in the presence of a human disturber, the broods spend more time on the water because they are safe; their mobility is much greater on the water, and potentially they can escape by diving. Secondly, the broods will start foraging unless threatened directly by the disturber, as foraging is the most important activity when on the water. This suggests some kind of tolerance to human activity and may be viewed as an adaptation, possibly evolved by living in areas with constant threat from human activities, or simply because broods cannot tolerate losing too much of their foraging time. Such a suggestion is also supported by the fact that broods quickly resumed foraging after being disturbed although, in most cases, the source of disturbance was still present. In a study of Eider ducklings Somateria mollissima, the decrease in foraging time was only significant at low tide, 5-10 minutes after a disturbance (Keller 1991), indicating that foraging in this species also is not affected by disturbance for very long. The same could be concluded from a study of adult Coots Fulica atra (Nielsen 1991).

\section{Compensatory behaviour}

For the species mentioned above, there is apparently no need for compensatory foraging as not much foraging time is lost by disturbance. Alternatively, they may simply not be able to compensate. This was suggested in studies of Brent Geese Branta bernicla (Owens 1977) and Wigeon Anas penelope (Madsen et al. 1992). The main reason for the inability to compensate for lost feeding amongst Brent Geese was claimed to be constraints on food availability (Owens 1977). In Wigeon, it was thought that, for a species which already expends over $90 \%$ of its day feeding in the absence of human activity, there is little opportunity to extend the period spent foraging when human activity is present (Madsen et al. 1992). The only successful example of compensatory foraging so far recorded was Mute Swans Cygnus olor in a situation where a flock stopped foraging for more than one hour after being disturbed (Madsen et al. 1992). Mute Swans only forage about $65 \%$ of total time, leaving sufficient extra time to recoup foraging time from non-essential activities after a disturbance.

In the present study, the deficit of forag- ing, built up after a disturbance, was not compensated during the $1^{1 / 2}$ hour watch after a disturbance. Apparently, Merganser broods give priority to making-up for insufficient comfort activities at the expense of foraging. This surprising order of priority may be due to limited endurance by the ducklings; e.g., for fish-eating species there may be some constraints on the time which can be spent on foraging (diving) (Nilsson 1969, Ydenberg 1988, Ydenberg \& Forbes 1988). Furthermore, the ducklings may be restricted in foraging by thermo-regulatory aspects. It is well known that ducklings of the Mergini tribe cannot thermo-regulate until they are over three weeks of age (Koskimies \& Lathi 1964, Kear 1970). The need for rest and brooding by the female may therefore be crucial. Whether the broods compensated for the foraging deficit later on could not be determined directly, but in the Årø broods, which experienced a high rate of disturbance, the percentage of foraging was not different compared to broods from other areas with lower rate of disturbance. This actually suggests some mechanism of full compensation of the foraging deficit over time. However, this simplistic analysis should be viewed with caution, as food availability may have influenced the overall time budgets.

\section{Aspects of management}

Although some negative effects of disturbance expressed through modifications to the time budgets and reduced survival were detected during the study, the general impression is that broods of Red-breasted Merganser have a high threshold of tolerance towards human activities. This suggestion is supported by the facts that 1) panic response to human activity (diving, flying, and divisions of broods) were rather rare; 2) the Merganser broods resumed their former activity shortly after a disturbance; 3 ) although forced into the water by some human activities; the Mergansers were able to adapt and in some cases even increase foraging time; 4) the Mergansers were able to compensate for time lost by disturbance and 5) in spite of differences in the frequency of disturbance between areas, Hejls being considered as rather undisturbed and Gudsø being six times more disturbed, the time budgets and sur- 
vival of broods did not differ between the two areas. Only at Årø, the most disturbed area, was the overall time budget modified with less time being spent on comfort. Reduction in the time spent on comfort was clearly demonstrated in the presence of water-based activities and, in particular, as a result of windsurfers which were frequent at Årø. It is now tempting to suggest that the frequent disturbance by windsurfers caused the significant reduction in breeding success. In support of that assertion is the crucial need for comfort activities after a disturbance as discussed in the context of compensatory behaviour. This unfulfilled need for comfort behaviour may therefore have caused deaths due to exhaustion and chilling.
To conclude, human disturbance may affect populations of Mergansers locally when disturbance is frequent and/or high-speed boating is present. Overall, the Baltic population is probably not threatened at the moment. However, there are many areas with intermediate levels of disturbance today, like Gudsø, where increased tourism may put the level beyond the Merganser threshold of tolerance and, as a result, reduce the population. Conservationists and administrators should therefore be careful when legislating on leisure use of coastal areas, and also take into consideration late-breeding and less spectacular species.

The study was grant-aided by the Dept. of Zoology, University of Århus, and computing facilities were provided by the National Environmental Research Institute, Dept. of Wildlife Ecology. I also want to thank $H$. Noer and S. Toft for supervising the project, and J. Madsen, A.D. Fox, J.K. Larsen, and T. Bregnballe for commenting on earlier drafts of the manuscript. C. Hansen and T. Pauli were helpful in organizing data, and J. Nordstrøm, YMCA-scouts in Denmark, gave permission to study in Gudsø.

\section{References}

Åhlund, M. \& Götmark, F. 1989. Gull predation on Eider ducklings Somateria mollissima: Effects of human disturbance. Biol. Conserv. 48:115-127.

Altmann, J. 1974. Observational study of behaviour: sampling methods. Behaviour 49:227-267.

Berger, T.R. 1977. The Berger report: northern frontier, northern homeland. Liv. Wildern. 41:4-33.

Bergman, G. 1956. Om kullsammanslagning hos skrakar, Mergus serrator och Mergus merganser. Fauna och Flora 51:97-110

Bregnballe, T. \& Madsen, J. 1990. Post-hatching behaviour of Light-bellied Brent Geese Branta bernicla hrota. Wildfowl 41: 27-34.

Brouwer, H. \& Daalder, R. 1984. Plankzeilen in natuurgebieden. Recreatie en toerism $16: 138-142$.

Burger, J. 1981. The effect of human activity on birds at a coastal bay. Biol. Conserv. 21:231-241.

Cramp, S. \& Simmons, K.E.L. 1977. The birds of the Western Paleartic. Vol. 1. Oxford Univ. Press, Oxford.

Dietrich, K. \& Koepff, C. 1986. Wassersport im Wattenmeer als Störfaktor für brütende und rastende Vögel. Natur und Landschaft 61:220-225.

Edington, J.M. \& Edington, M.A. 1986. Ecology, recreation and tourism. Cambridge Univ. Press.

Kear, J. 1970. The adaptive radiation of parental care in waterfowl. In: Social behaviour in birds and mammals (Ed. J.H. Crook). Academic Press, London, pp. 357-392.

Keller, V.E. 1991. Effects of human disturbance on Eider ducklings Somateria mollissima in an estuarine habitat in Scotland. Biol. Conserv. 58:213-228. 
Koskimies, J. \& Lathi, L. 1964. Cold-hardiness of the newly-hatched young in relation to ecology and distribution in ten species of European ducks. Auk 81:281-307.

Laursen, K. 1982. Recreational activities and wildlife aspects in the Danish Wadden Sea. Schriftenreihe des Bundesministers für Ernährung, Landwirtschaft und Forsten 275:63-81.

Leito, A. \& Renno, O. 1983. Über die Zugökologie der an der Barentssee heimischen Population der Weisswangengans Branta Leucopsis in Estland. Vogelwarte 32:89-102.

Madsen, J. 1985. Relations between change in spring habitat selection and daily energetics of Pink-footed geese Anser Brachyrhynchus. Ornis. Scand. 16:222-228.

Madsen, J., Frikke, J., Bøgebjerg, E., Kristensen, J.B., \& Hounisen, J.P. 1992. Forsøggsreservat Nibe Bredning: Baggrundsundersøgelser efteråret 1985 til foråret 1989. Danmarks Miljøundersøgelser. Faglig rapport DMU no. 46.

Matthews, G.V.T. 1982. The control of recreational disturbance. In: Managing wetlands and their birds, a manual of wetland and waterfowl management (Ed. D.A. Scott). Proc. 3rd technical meeting on Western Paleartic migratory bird management, Biologische Station Rieselfelder Münster, 12-15 Oct. 1982, pp. 325-330.

Mosbech, A. \& Glahder, C. 1991. Assessment of the impact of helicopter disturbance on moulting Pink-footed Geese Anser brachyrhynchus and Barnacle Geese Branta leucopsis in Jameson Land Greenland. Ardea 79:233-238.

Nielsen, A.F. 1991. Tidsbudget og fourageringsstrategi hos Blishøne Fulica atra $i$ Limfjorden om efteråret og adfordsmoessig reaktion på menneskelige aktiviteter. Unpubl. M. Sc. thesis, University of Århus, Denmark.

Nilsson, L. 1969. Knipans Bucephala clangula beteende under vinterhalvåret. Vår Fågelvärld 28:199-210.

Owen, M. 1973. The management of grassland areas for wintering geese. Wildfowl 24:123-130.

Owens, N.W. 1977. Responses of wintering Brent Geese to human disturbances. Wildfowl 28:5-14.

Pedroli, J.C. 1983. Activity and time budget of Tufted Ducks on Swiss lakes during winter. Wildfowl 33:105-112.

Prater, A.J. 1981. Estuary birds of Britain and Ireland. Poyser, Calton.

Schilperoord, L. \& Schilperoord-Huisman M.S. 1981. De invloed van verstoringen op gedrag en dagindeling van de kleine Rietgans Anser brachyrhynchus in Zuidwest Friesland. Unpubl. M.Sc. thesis, Univ. of Groningen, Netherlands.

Schneider, M. 1987. Wassersportler stören Wasservögel auch im Winter. Vogelwelt 108:201-209.

Tuite, C.H., Hanson, P.R., \& Owen, M. 1984. Some ecological factors affecting winter wildfowl distribution on inland waters in England and Wales, and the influence of waterbased recreation. J. Appl. Ecol. 21:41-62.

Vandermotten, C. (1990). L'Europe et ses regions: diagnostic interregional. Charleroi.

Ydenberg, R.C. 1988. Foraging in diving birds. Acta Congr. Int. Orn. 19:1832-1842.

Ydenberg, R.C. \& Forbes, L.S. 1988. Diving and foraging in the Western Grebe. Ornis Scand. 19:129-133.

Johnny Kahlert, Department of Zoology, University of Århus, DK-8000 Århus C, Denmark * Present adress: Department of Wildlife Ecology, National Environmental Research Institute, Kalø, DK-8410 Rønde, Denmark 